\title{
Ideologias do profissionalismo em disputa na magistratura paulista'
}

MARIA DA GLORIA BONELLI

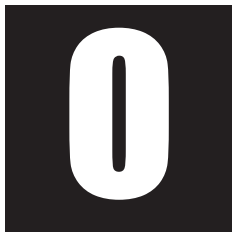

artigo contrasta o ideário dominante no Tribunal de Justiça do Estado de São Paulo (TJESP), com o ideário difundido pela Associação dos Juízes para a Democracia. Analisa os periódicos Revista de Jurisprudência do TJESP entre 1986-1997 e Jornal Juízes para Democracia, entre 19962002. O objetivo é identificar a luta cognitiva em torno do conteúdo do profissionalismo.

Além de investigar a mídia própria da magistratura, o estudo também aborda a visibilidade pública dos magistrados do TJESP na grande imprensa, considerando que esta imagem perpassa os embates internos, o processo de identificação e de redefinição de identidades coletivas na carreira. Focaliza a Folha de S. Paulo entre 1994-2002.

Os magistrados aparecem como uma corporação coesa em vários estudos, seja partilhando valores comuns cimentados ao longo de anos de socialização na carreira (Bonelli, 2002; Junqueira, et alii, 1997), seja reforçando os interesses da classe dominante (Koerner, 1998). Mesmo quando se fazem diagnósticos de mudança no sistema de valores que orienta a magistratura, a passagem de uma visão tradicional para uma mais moderna ocorre em bloco (Vianna, et alii, 1997). Passa-se de uma antiga visão

\footnotetext{
* Doutora em Sociologia pela Unicamp. Depto. de C. Sociais da UFSCAR. gbonelli@uol.com.br 1 Esta pesquisa conta com financiamento do CNPq e da FAPESP.
} 
dominante para uma nova visão dominante, como se isso resultasse das alterações na composição social do grupo ou do entorno social, das mudanças na sociedade, sem que existisse internamente uma minoria travando lutas cognitivas para dar novos sentidos ao fazer profissional.

Trata-se de uma percepção de profissão como unidade, no singular. É uma visão impregnada por um significado de profissionalismo que dá ênfase à sua capacidade geradora de sentimentos partilhados, decorrentes da crença no mérito, na expertise e na autonomia.

O objetivo do estudo é repensar tal forma de se conceberem os grupos profissionais através da problematização deste ideário. Embora o pertencimento a carreiras venha acompanhado de fronteiras simbólicas que demarcam campos e identificações comuns, dando coesão aos grupos profissionais quanto a aspectos de sua prática e a normas que a orientam, isto não os unifica em torno da concepção que têm de como estas atividades devem ser significadas e simbolizadas. A auto-imagem do juiz e as representações coletivas sobre a profissão não estão sujeitas aos mesmos constrangimentos institucionais e ao mesmo tipo de sociabilidade vivida numa ordem marcada por maior rigidez nas formas de identificação dos profissionais com seu grupo. Tais representações mudam em ritmo mais rápido quando são impulsionadas por agendas globais que vocalizam a urgência da democratização, pressionando governos nacionais a diminuir o risco interno e garantir maior capacidade e predição para o investimento de capital estrangeiro em países com Judiciários pouco previsíveis. Foi nesse contexto de pressões da ordem mundial para garantir decisões isentas dos Judiciários locais, na defesa de interesses econômicos internacionais no mercado, que a pluralização do ideário do profissionalismo eclodiu entre os juízes. Este cenário não sustenta mais a unicidade das concepções profissionais mesmo entre magistrados que vivenciam longos processos de socialização na carreira.

A proposta analítica adotada toma as disputas em torno do conteúdo do profissionalismo como indicativas da luta cognitiva entre identidades 
coletivas distintas na magistratura. $\mathrm{O}$ trabalho desenvolve reflexões sobre formas identitárias, ideologia do profissionalismo e mídia, procurando articulálas na compreensão do fenômeno profissional na atualidade.

A pesquisa apóia-se na conceituação de Dubar (2000) sobre as formas identitárias como modos de identificação dos indivíduos e localiza na magistratura o predomínio de duas das quatro formas definidas por este autor. Quanto ao profissionalismo, concebe-o como um campo com contornos mutáveis devido às diferentes visões sobre isenção e compromisso político, sobre ética e responsabilidade profissional (Sarat e Scheingold, 1998). No que diz respeito à abordagem sobre a mídia, o trabalho prioriza o enfoque do newsmaking e da análise de enquadramento (Hohlfeldt, 2001; Motta, 2002; Porto; 2002), enfatizando a interação dos magistrados no processo de produção das notícias, sem perder a dimensão da recepção da imagem do grupo por ele mesmo.

A visibilidade pública da magistratura constitui-se no principal material de análise, tanto no periódico oficial do TJESP e naquele em que juízes apresentam uma alternativa à atuação desta instituição, quanto na grande imprensa paulista. Concebem-se aqui as identificações profissionais dos juízes como resultado não só das interações práticas, mas da forma como eles se vêem e são vistos nos meios técnicos de difusão de bens simbólicos (Thompson, 1998).

\section{Grupos profissionais, formas identitárias, self e mídia}

A concepção interacionista simbólica será tomada como referência para pensar tanto as dinâmicas identitárias na magistratura e seus reflexos sobre o ideário do profissionalismo quanto a relação dos juízes com a mídia. No primeiro caso, constrói-se a argumentação sobre o pertencimento e a continuidade de certa coesão nas carreiras com formas identitárias plurais, aplicando-se tal teorização às lutas cognitivas travadas entre os juízes, através da análise de conteúdo e de discurso dos dois periódicos profissio- 
nais. Assim, um aspecto da alteridade é interno à carreira. Ele é observado no contraste entre os ideários da Revista de Jurisprudência e do Jornal Juízes para a Democracia (JD).

No segundo caso, a visão interacionista se apoiará na concepção de self como máscara e como espelho (Strauss, 1999) para analisar a imagem dos juízes na grande imprensa, seus reflexos sobre a mídia interna e sobre a pluralização das identificações coletivas na magistratura paulista.

Dubar parte do estudo de Elias $(1990,1993)$ sobre o processo civilizador, que aponta as conseqüências deste fenômeno sobre a balança Nós-Eu, intensificando a individualização na modernidade. Formando quatro tipos a partir da combinação da relação Nós-Eu para si e para os outros, Dubar formula a seguinte teorização sobre as formas identitárias:

1) A forma "biográfica para os outros" é de tipo comunitária, centrada em um "eu nominal", na qual perdura o pertencimento herdado culturalmente e a supremacia do Nós sobre o Eu, caracterizando a identificação cultural. 2) A forma "relacional para os outros" refere-se às interações no seio de um sistema instituído e hierarquizado, como a família, a escola, os grupos profissionais, o Estado.É uma identidade que implica um "eu socializado" pelo desempenho de papéis, caracterizando as identificações estatutárias ou categoriais. 3) A forma "relacional para si" provém de um si mesmo reflexivo, engajado ativamente na construção de um projeto, em associação com pares que também o partilham. Caracteriza a identidade em rede, por solidariedade e afinidades. 4) A forma "biográfica para si" provém de um si narrativo que busca ser reconhecido não somente pelos outros significativos, como no eu reflexivo, mas também pelos outros generalizados. É um processo biográfico acompanhado de crises. A identidade narrativa é aquela de uma visão ética que dá um sentido à existência inteira (Dubar, 2000, p. 54,55).

Este estudo identifica duas formas identitárias na magistratura: as identificações estatutárias predominam na análise da Revista de Jurisprudência do TJESP e o si mesmo reflexivo predomina no Jornal JD, configurando as 
formas identitárias "relacional para os outros" e "relacional para si" que convivem na instituição disputando os significados e a legitimidade da interpretação sobre o fazer profissional e suas representações coletivas. A Revista de Jurisprudência foi criada em 1968 e o Jornal Juízes para a Democracia em 1993.

O ideário do profissionalismo democrático aproxima-se mais da identificação por afinidades que predomina entre os membros da Associação dos Juízes para a Democracia. A concepção desse tipo de profissionalismo foi teorizado por Olson e Dzur (2004). Segundo eles, as respostas às críticas radicais ao profissionalismo tecnocrático levaram a propostas de ampliação da participação leiga na escolha e na prestação de serviços reservados aos profissionais, combatendo o monopólio desse mercado. Entre os críticos desse modelo profissional estão Foucault e Habermas.

O ideal do profissionalismo democrático dá a volta na crítica radical, no estilo do jiu-jitsu, e argumenta que se os profissionais podem ser amortecedores entre elites e cidadãos, eles também podem se retirar como amortecedores; se eles podem tomar para si tarefas do público e imobilizar a ação cívica, eles podem devolver estas tarefas e ativar a ação cívica; se os críticos das profissões podem ser suficientemente auto-conscientes para reconhecerem as faltas e limites da tecnocracia, então também podem outros profissionais treinados em instituições similares e influenciados pelas mesmas correntes de pensamento(...) (Olson e Dzur, 2004, p. 149).

A atribuição de novos significados ao profissionalismo é inerente à pluralização das formas identitárias nas carreiras profissionais. No caso dos juízes, este fenômeno tem sido impulsionado pela visibilidade que alcança ao ser enquadrado como notícia. A análise de conteúdo da imagem dos juízes na grande imprensa é o terceiro componente da triangulação que este trabalho constrói, ao pensar os processos de identificação dos magis- 
trados através da pesquisa na mídia. Esta perspectiva é viável porque focaliza uma carreira poderosa, com forte presença nos meios de comunicação.

Os juízes fornecem informações e matérias para os periódicos profissionais e para os jornais. Assim, são sujeitos ativos na produção de notícias, embora sejam nomeados de "fonte" nas teorias de mídia. Também são alvos de reportagens, sendo assim enquadrados. Esta visibilidade reforça o impacto dos veículos de comunicação nas percepções que os magistrados têm de si e dos outros.

Concebemos a relação dos juízes com estas mídias em três níveis: atuando sobre o processo de produção, objetivados no enquadramento da notícia, e como receptor de informação, especialmente daquela sobre sua imagem pública. Assim, a ruptura institucionalizada entre produção e recepção de bens simbólicos que predomina nos estudos sobre comunicação de massa, perspectiva compartilhada pela abordagem interacionista de Thompson (1995, p. 289), é relativizada aqui.

Os modelos teóricos sobre newsmaking dão ênfase excessiva aos critérios auto-referidos dos profissionais da comunicação no fazer da notícia e perdem a dimensão da participação de outros atores sociais poderosos neste processo. Tais atores aparecem como fonte, e a mensagem que difundem, como noticiabilidade (Hohfeldt, 2002). A concepção apresentada aqui resgata a dimensão de poder e de legitimidade social dos magistrados para falar sobre temas de justiça, segurança pública, direitos humanos, crimes, Judiciário, entre outros, o que os colocam em uma posição privilegiada na difusão destas informações. As relações dos juízes com a mídia não se ajustam ao modelo que identifica uma ruptura fundamental entre a produção e a recepção da notícia. As matérias sobre o Judiciário não são apenas resultado dos enquadramentos feitos pelos jornalistas. A característica apontada por Thompson (1995, p. 290), da mediação que o meio técnico estabelece entre o produtor e o receptor da informação, não é plena para os juízes, já que eles influenciam e intervêm no processo de produção, não configurando um fluxo de mensagem de mão única entre o 
produtor e o receptor.

Neste sentido, o self e a identidade dos magistrados com a carreira e os pares profissionais resultam de um processo interativo direto na produção da notícia, e de uma interação mediada como receptores (Thompson, 1998). Na última posição, eles recebem também notícias sobre si e seu grupo. Na produção da notícia, o self atua como máscara e na recepção da informação, como espelho (Strauss, 1999). Na relação com a mídia, os juízes acionam as características de máscara do self procurando influenciar a percepção pública da carreira e da atuação da magistratura, apresentando-se como querem ser vistos. Eles se antecipam à formação da opinião procurando dar-lhe uma direção e um formato. Já o lado do self que funciona como espelho é aquele em que os juízes vêem a si mesmos através da imagem coletiva refletida na mídia.É esta reflexão e auto-reflexão associada à relativa indeterminância dos sentidos atribuídos ao pertencimento à carreira que permitem o distanciamento de juízes em relação à visão dominante sobre o ideário profissional, diversificando as formas identitárias.

O reflexo de si na mídia gera tensão também entre os magistrados com identificação do tipo estatutária, como observado na análise da Revista de Jurisprudência, embora a maneira como eles a vivenciem seja característica da forma relacional para o outro, e não da conversão para a forma relacional para si, experimentada na AJD.

As tensões entre o self e a imagem dos magistrados na mídia provocariam, na visão de Dubar, crises de identidade. Nesta pesquisa, o choque entre o self ideal, o modelo de juiz que este profissional quer ser, e o reflexo de si na mídia é teorizado a partir do conceito de trabalho das emoções, de Hochschild (2003).

A conversão entre uma forma identitária e outra não ocorre necessariamente através de crises. Tal percepção pressupõe uma concepção estática dos processos identitários (Strauss, 1999). Se eles são concebidos de maneira dinâmica, as mudanças geram choques, conflitos, mas são vividas ativamente, através da atuação do eu sobre si mesmo e sobre os outros, 
trabalhando os sentimentos e as emoções para moldar o self às interações. Segundo Hochschild, o trabalho das emoções não se resume à atuação na superfície do eu, como em Goffman. O enquadramento dos sentimentos requer uma atuação profunda, para que o self sinta a interação de forma diferente. Sua abordagem também contrasta com a de Freud, porque ela considera como as pessoas sentem conscientemente e atuam para moldar as emoções, em vez de conceber os sentimentos como inconscientes (Hochschild, 2003, p. 94).

Através do trabalho emocional para adaptar o self às novas circunstâncias, os juízes acessam os códigos profissionais disponíveis - tradicionais e modernos - combinando-os. Esse mix atenua a polarização na carreira e permite que a pluralização das formas identitárias não resulte em ruptura da magistratura.

Para análise das manifestações discursivas que constituem a base de dados desta pesquisa, a concepção de enquadramentos de mídia que utilizamos apóia-se em Porto (2002), que retoma o conceito desenvolvido por Goffman no livro Frame Analysis.

Nesta obra, Goffman define enquadramentos como os princípios de organização que governam os eventos sociais e nosso envolvimento nesses eventos. Segundo o autor, tendemos a perceber os eventos e situações de acordo com enquadramentos que nos permitem responder à pergunta: 'O que está acontecendo aqui'. Nesse enfoque, enquadramentos são entendidos como marcos interpretativos mais gerais construídos socialmente que permitem às pessoas fazer sentido dos eventos e das situações sociais (Porto, 2002, p. 4).

Assim, esta pesquisa concebe a notícia como um empreendimento negociado (Tuchman, 1978). A construção social da notícia envolve o processo de definição da situação, conceituado no interacionismo simbólico (Strauss, 1999). A definição da situação é parte fundamental do processo 
de decidir como agir, o self atua a partir deste enquadramento prévio. Dependendo da maneira como a pessoa define a situação, ela se prepara para uma interação conflituosa, harmônica, tensa, afetuosa, etc.

No caso da notícia, definir que um evento da realidade e não outro qualquer é uma informação publicável já recorta aspectos do real a partir deste enquadramento. Portanto, o primeiro empreendimento negociado é a interação entre formas distintas de se definir a situação do que é ou não noticiável. Juízes e jornalistas selecionam aspectos diferentes da realidade para divulgar nas mensagens. O enquadramento que é publicado em cada um destes meios técnicos difere em função do resultado da interação negociada, mesmo que tal relação se estabeleça de forma assimétrica. Nos periódicos da magistratura predominam as definições das situações enquadradas principalmente pelos juízes. Na Folha de S. Paulo predomina o perfil do jornal, ${ }^{2}$ resultado de um outro processo de negociação para a construção da notícia, onde os jornalistas ganham força.

\section{Metodologia e trabalho de campo}

A Revista de Jurisprudência do Tribunal de Justiça do Estado de São Paulo é o periódico oficial do TJESP, sendo dirigida por desembargadores do Tribunal. ${ }^{3}$ A revista é custeada pelas verbas votadas na Assembléia Legislativa para o Poder Judiciário. Ela começou a circular em 1967, com periodicidade trimestral. Em 1976 passou a ser bimestral e, em 1993, tornou-se uma publicação mensal. A seção "Noticiário", que foi objeto prioritário de análise da pesquisa, só começou a ser publicada em 1968. Nela, os desembargadores divulgam os discursos proferidos nas solenidades. As seções centrais da revista são a de doutrina e a de jurisprudência. Os discursos analisados foram realizados em solenidades de instalação do 
ano judiciário, de homenagens póstumas, de posse de novos desembargadores, de visitas de autoridades ao Tribunal de Justiça, de comemorações de centenários, etc. ${ }^{4}$

O contexto de criação da revista é de endurecimento do regime militar, com a promulgação de Atos Institucionais culminando, em 1968, com o Al -5, que comprometeu a independência do Judiciário, acompanhada de cassações, remoções e aposentadorias forçadas de juízes. Setores liberais civis que apoiaram a tutela militar para conter a radicalização política na sociedade começaram a se distanciar do regime e a ingressar na oposição nesse período, como ocorreu com a OAB.

A Revista de Jurisprudência publicou 100 números entre 1986-1997, totalizando 299 manifestações discursivas classificadas para o período no acervo do grupo de pesquisa "O mundo profissional do Direito e as relações com o Estado".

O Jornal JD é o órgão de difusão do ideário da Associação dos Juízes para a Democracia, organizada em 1991. A AJD divulga entre seus objetivos dar apoio integral ao Estado Democrático de Direito; mobilizar-se pela proteção efetiva aos direitos substanciais do homem não se restringindo aos direitos formais; defender a independência do Judiciário; lutar pela democratização da magistratura e a transparência da justiça; comprometer-se com a defesa das minorias visando sua efetiva emancipação; promover a solidariedade entre os operadores do Direito e apoiar a democracia pluralista. A partir de 2000, o jornal consegue manter a periodicidade trimestral. A tiragem atual é de vinte mil exemplares, com distribuição nacional entre operadores do Direito, congressistas e representantes de entidades da sociedade civil. Segundo informações do secretário do Conselho Executivo, o magistrado Antonio Carlos Villen, a associação conta com cerca de trezentos sócios, a grande maioria, do Estado de São Paulo. Segundo o site $^{5}$ da AJD, o jornal "relata as atividades periódicas da

4 Informações extraídas de Campos (1999) e de Junqueira (1998). 
Associação, os posicionamentos assumidos e manifestações encaminhadas, e uma importante coletânea de artigos escritos por associados e não associados sobre o mundo do Direito".

O número de jornais investigados foi de 23, embora ele já estivesse na edição 31. A coleta começou no número 6, publicado em 1996, porque é a partir daí que os textos estão disponíveis on line. Foram selecionadas 375 matérias. O critério de seleção partiu do editorial, porque o jornal define a temática central do número e pauta um conjunto de textos sobre o assunto para completar a edição, escritas por membros da AJD ou por outros autores com posições semelhantes à da associação sobre a questão em foco. Esses artigos geraram 430 manifestações discursivas classificadas. ${ }^{6}$

A base de dados coletadas da Folha de S. Paulo começa em 1994 porque é para este ano que há disponibilidade on line do jornal diário. A palavra-chave juiz foi definida para se fazer a seleção inicial das matérias. Todos os textos em que ela apareceu passaram por uma análise suplementar, preservando-se aquelas que se referiam aos juízes do TJESP, excluindo-se as demais. Também foram desconsiderados os textos onde havia uma simples menção à palavra, como a qualificação da autoria de um livro. Todas as matérias que versavam sobre a justiça civil e criminal de São Paulo, que se referiam a ela ou que eram escritas por seus juízes foram selecionadas. Definido tal corpus $^{7}$ da pesquisa, todos os textos que se encaixaram nessa delimitação foram classificados, incluindo aqueles não produzidos pelos jornalistas, como as colunas de opinião e cartas de leitores.

Para os anos de 1994/1999, a base de dados foi cedida por Castro (2002). Ela selecionou 427 notícias, que geraram 550 manifestações discursivas. Essa base foi atualizada pela equipe do projeto para os anos 2000/2002. ${ }^{8}$ O número de notícias selecionadas para esse último período

$5<$ www.ajd.org.br>

6 Trabalho de campo realizado por Leandro Targa. O tratamento dos dados contou com a assessoria de Fabiana Luci de Oliveira.

7 Segundo Bardin (1979), o corpus da pesquisa é o conjunto de comunicações que, de fato, será objeto de análise. 
foi de 605, que geraram 696 manifestações discursivas. Portanto, o total é de 1032 matérias e 1246 manifestações discursivas classificadas, para o período 1994-2002.

Além desta análise quantitativa, as manifestações discursivas são consideradas em sua dimensão qualitativa para a compreensão das lutas cognitivas em torno do ideário e das representações dos juízes. Uma parte da apreensão desses significados foi auxiliada pela realização de entrevistas em profundidade com membros da AJD e do Tribunal de Justiça.

\section{A análise dos resultados}

Embora esta pesquisa tenha transformado em quantidades conteúdos qualitativos sobre os ideários manifestos na Revista de Jurisprudência e no Jornal dos JD, as diferenças entre estes dois periódicos não se resumem às percentagens obtidas. A Revista de Jurisprudência cumpre a função de divulgar para todos os operadores do Direito a jurisprudência do TJESP, além da doutrina. Trata-se de uma atribuição do Poder Judiciário do Estado de São Paulo. É principalmente nos discursos proferidos em solenidades e publicados na seção Noticiário que identificamos a visão de mundo dominante no Tribunal.

O Jornal Juízes para a Democracia difunde a visão de mundo da AJD. Trata-se de uma associação de adesão voluntária, que aceita como sócios juízes em todo o território nacional, nas diversas esferas e especializações da justiça. O que os une é o partilhar de valores semelhantes quanto ao compromisso político dos juízes com a efetivação de uma democracia pluralista e inclusiva para a sociedade e para o Judiciário.

As diferenças entre os dois periódicos são evidentes no conteúdo de várias manifestações discursivas, embora classificadas na mesma categoria. O contraste entre estes ideários é que justifica a abordagem das lutas cognitivas para legitimar novas formas de se conceber o profissionalismo. 
As manifestações discursivas classificadas na variável "percepção sobre a ordem social e mundial" ilustram as diferenças entre os dois ideários. A passagem abaixo foi extraída do discurso pronunciado pelo desembargador Benini Cabral, na solenidade de abertura do ano judiciário de 1994.

(...) O desejo popular, nos dias difíceis por que passamos, não difere daqueles das camadas mais altas e responsáveis. Deseja-se, para o assentamento revisional da Constituição, o respeito ao verdadeiro estado de direito no país; menos impostos e um sistema tributário mais simples e justo; melhores salários aos trabaIhadores; proteção à saúde pública, à cultura e ao ensino; aos menores e idosos; à ecologia; ao direito de nossos índios; do meio ambiente; de nossa fauna e flora; das nossas riquezas naturais e do resguardo da nossa Amazônia; das nossas fronteiras; dos direitos dos presos; da liberdade religiosa; a defesa da moralidade administrativa; de uma melhor distribuição de renda; do combate à corrupção, em todos os níveis; do enxugamento do déficit público; prover o controle cambial; manter o direito das raças e a nenhuma discriminação; o término da inflação monetária; instalar uma política externa realista, compatível com o tamanho de nossa economia; pelas privatizações necessárias; fomentar o civismo, para, enfim, afastar a descrença e a depressão populares, pondo-se 'ordem no pensamento nacional'. O fulcro maior, disse-o, há tempos, o Brigadeiro Eduardo Gomes: 'A um futuro melhor, podemos e devemos chegar pela verdadeira democracia. Progredindo numa ordem social mais justa, na qual o triste espetáculo da opulência excessiva de uns não afronte a miséria extrema de outros'(...) (Cabral, B. RJTJESP 153, 1994). 
No período analisado, foram relativamente poucas as manifestações sobre a ordem social e mundial, na Revista de Jurisprudência. Além disso, várias delas não tinham um alvo direto, objetivo e identificável, dirigindo as críticas sociais de forma evasiva. Das 159 manifestações classificadas como ideário do TJESP, apenas $6 \%$ versavam sobre a percepção da ordem social e mundial. De longe, a maior ênfase foi dada aos elogios aos pares, com $88 \%$ das citações retiradas dos pronunciamentos. Esta concentração também decorre do fato de que vários dos discursos foram feitos em solenidades com o objetivo de homenagear colegas. O modelo de juiz e o status do Tribunal aparecem em $7 \%$ das ocorrências classificadas como ideário. Esse tipo de ideário era mais difundido nas solenidades de recepção aos novos juízes, dando o tom do processo de socialização na instituição.

Um exemplo da categoria modelo de juiz foi extraído do discurso do desembargador Silvio Lemmi, na posse dos juízes substitutos, em 1989.

(...) Colocados em posição privilegiada em relação aos demais cidadãos, já não tereis o direito de vos expressardes politicamente. Não tereis ideologias, nem preconceitos sociais ou religiosos. Em qualquer desses assuntos guardareis o silêncio da Trapa. Do mesmo modo, não podereis falar em classe ou categoria profissional, segundo a linguagem da legislação trabalhista. (...) (RJTJESP 116, 1989).

A ênfase no apoliticismo dos juízes reproduz o conteúdo dominante no ideário do profissionalismo. Segundo Halliday (1999), os custos da politização para as profissões foram elevados e, fazendo uma política própria, elas se caracterizaram como anti-políticas. O profissionalismo cívico, conceituado por esse autor, protege as profissões jurídicas da política convencional através da expertise e da autonomia. A habilidade em converter autoridade moral em expertise é a forma como o mundo do Direito exerce poder, com legitimidade social, apoiando-se nos valores do formalismo legal, do procedimentalismo e do conhecimento técnico-jurídico. As pro- 
fissões jurídicas não conseguiriam combinar a politização e essa autoridade moral, sem perder a legitimidade.

Já as manifestações discursivas do Jornal JD sobre as percepções da ordem social e mundial apresentam outro ideário e um estilo explicitamente crítico. Tal variável foi a que reuniu maior número de registros na base de dados desse periódico. Ela também apresenta mais autorias de fora da AJD, com artigos de advogados, professores de direito, membros do Ministério Público, cientistas sociais, políticos, representantes de ONG's e de movimentos sociais. As passagens classificadas aqui versavam sobre os direitos humanos, a crítica da adesão à Alca e o apoio ao Fórum Social Mundial, a defesa da cidadania para todos, da regulamentação do aborto legal, da democratização do Judiciário e do acesso à Justiça, entre outras. Os elogios aos pares, ao contrário do observado na Revista de Jurisprudência, obtiveram o percentual mais baixo das categorias classificadas como ideário da AJD. Já as citações que permitem inferir o reconhecimento externo, a legitimidade e a importância da associação foram significativas, revelando a auto-imagem e o enquadramento desses eventos como notícia. Tais registros ultrapassaram aqueles, difundindo os modelos de juiz e de Judiciário que o jornal propõe.

A passagem a seguir ilustra as concepções da AJD sobre a ordem mundial. Ela foi extraída do editorial "Adesão à Alca?".

(...)Bem revela a quem interessa fazer do continente americano - que está longe de ser a Europa -, uma área de livre comércio, que na verdade não é apenas 'livre comércio', mas dominação da economia mais poderosa do mundo sobre a Brasil, mediante pura desregulamentação da economia. (...) Há de decidir, então, se mais convém ao Brasil integrar-se à Alca ou negociar com a União Européia. Se convém 'aderir' à economia dos EUA, ao neocolonialismo que caracteriza mais e mais suas relações com a América Latina e o resto do mundo, ou integrar uma rede de solidarieda- 
de como a da Unidade Européia, que não se preocupa apenas com mercadorias e serviços, mas com pessoas e espaços para o exercício de liberdades. (...) a AJD, que já aderiu à campanha contra a Alca, concita a todos que participem e divulguem o plebiscito, que será realizado em setembro próximo. (Jornal JD 28, 2002)

Os enquadramentos das notícias sobre o Judiciário paulista na Folha não versam sobre a percepção social e mundial dos magistrados. As matérias sobre a magistratura paulista informam principalmente sobre processos famosos, sobre julgamentos e ordens de prisão, sobre manifestações ou decisões do Judiciário que representam benefícios para a sociedade e sobre resultados judiciais desfavoráveis aos outros poderes. Neste sentido, a cobertura jornalística é fundamental para construir e divulgar a imagem do Judiciário, na lógica da justiça em ação. A passagem abaixo ilustra a classificação de matérias na categoria Judiciário em ação.

O juiz Mauricio Valala, de Sorocaba (SP), decretou ontem de madrugada a prisão temporária do jornalista Antonio Marcos Pimenta Neves, 63, diretor doe redação do jornal "O Estado de S. Paulo". Ele é suspeito de matar a tiros a ex-namorada Sandra Gomide, 32, também jornalista, num haras, em Ibiúna, no interior de São Paulo. (...) (Folha de S. Paulo, 22/8/2000).

Por outro lado, também são enquadradas notícias formando representações simbólicas negativas sobre o Judiciário, como as denúncias de corrupção e as críticas da mídia.

O advogado José Alves de Brito Filho, acusado de integrar a chamada 'máfia dos fóruns', conseguiu sacar $R \$$ 1.046.424,54 de uma conta judicial na agência Liberdade do Banespa, apesar de não ser representante legal das partes envolvidas no processo, que desapareceu da $27^{a}$ Vara Criminal. A justiça silencia quando questionada sobre o caso.O juiz que autorizou o le- 
vantamento, Sérgio Ribas, da $27^{a}$ Vara Criminal, é o mesmo que denunciou à Corregedoria-Geral do Tribunal de Justiça ter recebido oferta de propina de um colega magistrado para acelerar o pagamento da ação. Como envolve juízes o caso é tratado em segredo (FoIha de S. Paulo, 25/8/2000).

Do total de 696 manifestações discursivas classificadas sobre o Judiciário paulista, publicadas na Folha de S. Paulo para o período entre 2000 e 2002, $18 \%$ delas são de autoria do juiz ou é ele quem fala no texto; a participação dos jornalistas como autores destas manifestações discursivas é de $72 \%$. É nas categorias sobre os benefícios específicos para a corporação, sobre os conflitos ideológicos da magistratura paulista e sobre as críticas do Judiciário ao Executivo e à mídia que os magistrados aparecem mais ativamente como autores da fala ou do texto. Nessas categorias eles não dispõem de porta-vozes, como ocorre nas passagens sobre o Judiciário em ação, nas quais os jornalistas, ao enquadrarem estes eventos como notícia, também difundem informações sobre a atuação dos juízes.

Os benefícios específicos são aqueles que demandam melhorias para o grupo profissional ou para o Judiciário. Foram incluídas nos benefícios corporativos as demandas por melhores salários, por mais equipamentos ou pessoal. Na segunda categoria, foram incluídos vários aspectos do debate sobre a reforma do Judiciário, que favorecem o funcionamento deste Poder. A Revista de Jurisprudência mostrou-se mais voltada para a difusão dos interesses específicos e da defesa de críticas, e o Jornal JD priorizou falar em nome da defesa de interesses societários. O Tribunal de Justiça tem na grande imprensa uma fonte de divulgação de seus atos e manifestações, tanto em benefício da sociedade quanto da instituição. Muitas vezes, o que é demandado para o Poder Judiciário é caracterizado no discurso como favorecendo também o bem comum e a coletividade. O noticiário da Revista de Jurisprudência tem uma circulação mais restrita ao mundo jurídico, e através dela os magistrados comunicam suas bandeiras e neces- 
sidades internas.

Nas matérias da Folha, que abordam os interesses expressos pelos juízes, percebe-se com transparência como a notícia é um empreendimento negociado. Através dos textos dos jornalistas, as informações do Tribunal de São Paulo circulam e são transmitidas no estado. O enquadramento que resulta da interação dos magistrados com os profissionais da imprensa não tem o formato de notícias interpretativas como são as matérias que fazem a defesa do Judiciário. A interação se concretiza na veiculação da informação sobre o cotidiano da justiça. A defesa do Judiciário, na Folha ou nos periódicos analisados, é feita principalmente pelos magistrados e demais operadores do Direito. Em sintonia com o perfil da Folha, as críticas e os conflitos são priorizados, sejam eles produzidos a partir da visão de outros setores sociais ou de autoria dos próprios jornalistas. Mesmo assim, a notícia também registra a colaboração e a harmonia entre os profissionais do Direito e da segurança pública, devido à atuação conjunta inerente ao funcionamento deste campo.

Os conflitos intraprofissionais não aparecem na Revista de Jurisprudência , entre 1986-1997, enfatizando-se principalmente a harmonia entre as profissões jurídicas, com $71 \%$ dos registros. Já no Jornal Juízes para a Democracia, os conflitos da AJD com o Judiciário correspondem a 59\% das manifestações discursivas classificadas, e a harmonia entre as profissões jurídicas atinge apenas 5\%. A cobertura da Folha faz a passagem da realidade do Tribunal à da Associação na forma como os juízes percebem suas relações no mundo profissional. No primeiro período analisado na base da Folha (1994-1999), predominam os conflitos intraprofissionais com 55\%, mas, no segundo período, as manifestações discursivas sobre conflitos interprofissionais chegam a $63 \%$, valor muito superior aos encontrados em ambos os periódicos dos magistrados. Não só a Folha reflete o processo de pluralização na identificação profissional como também o legitima e difunde. Juízes com posições mais conservadoras, mais moderadas ou mais radicais vêem a oportunidade de se manifestarem na grande imprensa. As duas 
citações abaixo extraídas da Folha foram classificadas nos conflitos internos ao Judiciário.

O juiz da $28^{a}$ Vara Criminal do município de São Paulo, Airton Vieira, 35, defende a Lei dos Crimes Hediondos e afirma que as penas são "até brandas". No entanto, ele acredita que o sistema prisional brasileiro não recupera ninguém. "Nem nenhum outro sistema no mundo. Por isso defendo a lei dos hediondos, que pelo menos afasta da sociedade, por um longo período, esses cidadãos marcados pela alta periculosidade", diz Vieira, que tem dez anos de carreira. "Não tenho nenhum constrangimento de assumir que sou favorável à pena de morte e à prisão perpétua", afirmou o juiz, que diz ter entre os colegas de magistratura fama de radical. Para Vieira, a criminalidade só se resolveria daqui a gerações, "mas como nada tem sido feito para atacar os problemas sociais, a violência tende a crescer, e precisamos de leis severas", diz o juiz. "Mesmo com todo o efeito punitivo, temos esses dados da escalada dos hediondos. Imagine, então, se a lei não tivesse sido criada. Tenho alergia a esses discursos liberais. Quero rigor no cumprimento das leis, sem privilégios, seja rico, seja pobre" (Folha de S. Paulo, 5/9/2000).

As penas alternativas, como são conhecidas as punições que podem substituir a prisão, alcançariam no máximo um universo de 6.222 presos no Estado de São Paulo, ou quase 13\% da população carcerária com sentença conhecida pelo sistema penitenciário estadual. Esse é o número de condenados por crimes de furto, estelionato, porte de arma e uso de drogas, cujas punições poderiam ser enquadradas na lei que regulamentou as penas alternativas. (...) Para o juiz da $5^{a}$ Vara Criminal Central, Edson Brandão, um dos pionei- 
ros no Estado a aplicar penas alternativas, o número de possíveis beneficiados deve ser muito menor. "Hoje em dia, não se manda mais para a cadeia o usuário de drogas, e, no entanto, mais de 400 pessoas aparecem na estatística como se estivessem presas por isso. Elas, com certeza, têm muitas condenações a cumprir e apenas estão registradas como cumprindo pena por uso de drogas.(...)" (Folha de S. Paulo, 5/3/2001)

Quanto às relações entre os poderes constituídos, a Revista de Jurisprudência priorizou a defesa da autonomia do Poder Judiciário. No período de 1986-1997, o debate sobre o controle externo teve muita evidência e os discursos dos magistrados deram ênfase à independência judicial. Neste sentido, as tensões com o Executivo delimitam claramente as fronteiras do Judiciário, preservando o sentimento dos juízes de partilhar a vida profissional em uma instituição autônoma. O Jornal JD apresentou muitas tensões com o Congresso e o governo federal. Por outro lado, as críticas da AJD ao Judiciário sobrepuseram as manifestações discursivas em defesa da autonomia desse Poder.

Exemplo de tal tipo de crítica encontra-se no editorial "Uma inconstitucional concentração de poderes", do Jornal Juízes para a Democracia:

Uma das primeiras preocupações do constitucionalismo foi justamente estabelecer limites jurídicos para o exercício do poder político, como o que o Judiciário, tal como os outros dois poderes, exerce. No Judiciário brasileiro, dadas as características da carreira da magistratura, o poder se concentra nos mais antigos, que sempre decidiram as questões mais importantes, da competência do Plenário do Tribunal ou da Câmara Especial. Não se pode, porém, por conta de tal realidade institucional - que em si já demanda aprimoramento -, ofender princípios fundamentais incertos na Constituição de Repú- 
blica quando se trata do exercício da jurisdição. (...) A sistemática ainda em vigor nos tribunais estaduais paulistas, além de discrepante da praticada pelo Supremo Tribunal Federal, pelo Superior Tribunal de Justiça e pelo Tribunal Regional Federal, ofende princípios constitucionais (Jornal JD 8, 1996).

As notícias publicadas na Folha sobre as decisões judiciárias desfavoráveis aos outros poderes são maioria nas categorias agrupadas como relações entre o Executivo, o Legislativo e o Judiciário. Estes enquadramentos dão visibilidade às fronteiras simbólicas entre os poderes de Estado para os receptores da informação, contingente que inclui também os juízes. A imagem pública da instituição é vista por seus membros, tanto em seus aspectos negativos quanto nos positivos. Se alguns aspectos reforçam a pluralização do ideário, outros influenciam o sentimento de pertencimento à magistratura, principalmente os que reafirmam a independência do Judiciário.

É a combinação destes dois fatores - a preservação da continuidade no tempo quanto ao pertencimento à carreira e a ruptura com a ortodoxia do ideário do Tribunal - que marcam as relações profissionais dos magistrados hoje e são permeadas pela forma como eles são vistos e se vêem na mídia. As formas identitárias que detectamos na Revista de Jurisprudência e no Jornal Juízes para a Democracia se constroem na alteridade entre elas e delas, com a grande imprensa. A forma identitária que predomina nas manifestações discursivas da Revista de Jurisprudência é aquela que Dubar (2000) chamou de identidade categorial, que fornece uma identificação para outro. No Jornal JD é a identidade de rede, construída por afinidades, que fornece uma identificação para si. Segundo o autor:

A primeira, a identidade categorial, é aquela que se inscreve dentro de uma continuidade, dentro de uma forma histórica pré-existente que Ihe fornece sua identificação principal (para outro). O coletivo pré-existe e 
performa a individualização. Essa não constitui nada além de uma especificação de tipo comunitário, ao mesmo tempo referencial e constrangente. (...) A segunda, a identidade de rede, é aquela que resulta de uma ruptura, que implica uma identificação nova (para si), que resiste à prova da individualização freqüentemente forçada, que enfrenta a questão da reconstrução de uma forma societária, ao mesmo tempo voluntária e incerta. (Dubar, 2000, p. 123).

A rede que apóia esta nova identificação em torno da AJD foi tecida internacionalmente através de elos com organizações semelhantes como a Associação dos Juízes para a Democracia da Espanha, criada em 1989, que foi seguida como modelo. A AJD participa do Fórum Mundial de Juízes. No Brasil, sua rede é composta de magistrados com identidade reflexiva, em torno de afinidades e solidariedades que extrapolam o pertencimento à carreira, articulando-se também com outros operadores do Direito, políticos, professores, intelectuais, representantes de ONG's e movimentos sociais que, em comum, partilham um ideal de justiça que contempla o efetivo acesso do cidadão e a democratização do Poder Judiciário.

Embora a identidade categorial predomine na Revista de Jurisprudência, o trabalho das emoções, que os magistrados realizam, devido ao choque entre o self ideal, a imagem dos juízes na mídia e a pluralização de formas identitárias, está presente em diversos discursos publicados na seção Noticiário. A identificação estatutária, relacional para outro, é afetada pela percepção que o Tribunal de Justiça tem deste olhar, ainda mais quando a alteridade passa a se localizar dentro da própria instituição. A representação simbólica do Tribunal como 'a família judiciária', repetida muitas vezes nas solenidades, choca-se com a luta cognitiva interna cuja heterodoxia interpreta tal 'união' como concentração e abuso de poder. 


\section{Conclusões}

O trabalho vinculou a literatura sobre profissionalismo, identidades coletivas e mídia para pensar o processo de pluralização das formas identitárias na magistratura paulista, a partir do estudo de dois periódicos internos e das imagens dos juízes na grande imprensa. A concepção que orientou a análise dos dados estabeleceu uma triangulação entre essas três mídias, relacionando a Revista de Jurisprudência com o conteúdo dominante da ideologia do profissionalismo e a identidade categorial. Este ideário enfatiza a neutralidade técnico-jurídica, o profissionalismo cívico, e é acompanhado da construção coesa da profissão.

O Jornal JD representa a heterodoxia profissional, com ideário e identificação distintos. No lugar da neutralidade, enfatiza a associação entre responsabilidade profissional e compromisso social articulada a uma identificação reflexiva. Trata-se de uma identidade em rede, construída a partir da afinidade e da solidariedade entre aqueles que resistiram ao processo de individualização forçado pelo Nós sobre o Eu, pela socialização na carreira, em detrimento do Si mesmo reflexivo.

A análise da base de dados da Folha completa a interpretação sobre como a imagem pública dos juízes foi um fator relevante na difusão desse processo de pluralização das formas identitárias. A cobertura jornalística, imprescindível para a circulação das informações que mostram como o Judiciário está em ação, também enquadram notícias críticas que espelham uma avaliação negativa sobre a atuação dos magistrados. Essa visão sobre si em descompasso com a auto-imagem do juiz gerou os processos de conversão identitária. Eles foram divulgados através dos periódicos e das redes profissionais. Definidos como notícia, chegaram à grande imprensa, realimentando a triangulação.

Uma questão está em suspenso no que diz respeito às mudanças no ideário do profissionalismo. Na análise das manifestações discursivas, observamos as lutas cognitivas entre o ideário da neutralidade e do compromisso social, mas o profissionalismo democrático vai além disto. Ele se 
retira da posição de amortecedor entre as elites e os cidadãos e devolve ao público as tarefas que havia concentrado para si. No que diz respeito à exclusividade sobre as atividades e à devolução de atribuições à cidadania para gerar mobilização da ação cívica, o Jornal JD manifestou-se apenas sobre o controle externo do Poder Judiciário, apoiando a criação de um órgão que inclua representantes da sociedade civil. Nada se disse sobre as reservas garantidas pelas regulamentações profissionais, embora se tenham adotado os juizados especiais como tipo de justiça informal . No âmbito de informalidade, o problema foi abordado quanto à obrigatoriedade ou à dispensa da participação de advogado das partes, mas não se cogitou como a autoridade do juiz poderia ser atenuada, partilhada ou devolvida à ação cívica nas "pequenas causas", aspecto considerado em outras experiências internacionais.

\section{Referências:}

BANCO MUNDIAL. Brazil Equitable, Competitive, Sustainable - Contributions for debate. Disponível em: <www.worldbank.org>. 2002

BARDIN, L. Análise de conteúdo. Lisboa: Edições 70. 1979.

BONELLI, M. G.. Profissionalismo e política no mundo do Direito. São Carlos: EDUFSCar/Sumaré/Fapesp. 2002.

BONELLI, M. G.. Ideologias do profissionalismo em disputa no mundo do Direito. São Carlos: UFSCar/DCSo. 2004.

CAMPOS, R. Os desembargadores paulistas e seus discursos: uma análise da Revista de Jurisprudência do Tribunal de Justiça do Estado de São Paulo, entre os anos de 1967 a 1997. São Carlos: UFSCar/DCSo. 1999.

CASTRO, C. M. Poder Judiciário paulista: imagem e competição por poder simbólico retratadas na mídia. São Carlos: UFSCar/PPGCSo. 2002.

DUBAR, C. La crise des identités: I'interpretation d'une mutation. Paris: Presses Universitaires de France. 2000. 
ELIAS, N. O processo civilizador. v. 1 e 2. Rio de Janeiro: Zahar. 1990, 1993.

HALLIDAY, T. Politics and civic professionalism: legal elites and cause lawyers. Law \& Social Inquiry, n. 24, p. 1013-1060. 1999.

HOCHSCHILD, A. R.. The commercialization of intimate life. Berkeley: University of California Press. 2003.

HOHLFELDT, A. Hipóteses contemporâneas de pesquisa em comunicação. In: HOHLFELDT, A., et alii. Teorias da Comunicação. Petrópolis: Vozes. 2001.

JUNQUEIRA, E. S. O diálogo entre profissionais do mundo do Direito paulista na abertura de anos forenses, 1967-1997. Monografia. São Carlos, UFSCar/DCSo, 1998.

JUNQUEIRA, E. B., et alii. Juízes: retrato em preto e branco. SP: Letra Capital Editora. 1997.

KOERNER, A. Judiciário e cidadania na constituição da república brasileira. SP: DCP USP/Editora Hucitec. 1998.

MOTTA, L. G.. Imprensa e Poder. Brasília: UnB. 2002.

OLSON, S. M. e DZUR, A. W. Revisiting informal justice: Restorative justice and democratic professionalism. Law \& Society Review, v. 38, n. 1. 2004.

PORTO, M. P. Enquadramentos da mídia e política. Caxambu, XXVI Encontro Anual da ANPOCS. 2002.

SARAT, A. e SCHEINGOLD, S. Cause lawyering: Political commitments and professional responsabilities. NY: Oxford University Press. 1998.

STRAUSS, A. Espelhos e Máscaras. SP: Edusp. 1999.

THOMPSON, J. B. A mídia e a modernidade: uma teoria social da mídia. Petrópolis: Vozes. 1998.

THOMPSON, J. B. Ideologia e cultura moderna. Petrópolis: Vozes. 1995.

TUCHMAN, G.. Making news. New York: The Free Press. 1978.

VIANNA, L. W., et alii. Corpo e alma da magistratura brasileira. RJ: Editora Revan/ luperj. 1997. 
Recebido: 13/09/2004

Aceite final: 20/10/2004

\section{Resumo}

O artigo contrasta o ideário dominante no Tribunal de Justiça do Estado de São Paulo, com o da Associação dos Juízes para a Democracia e com a imagem pública dos magistrados na mídia impressa. Vincula os diferentes conteúdos deste ideário com as teorias do profissionalismo cívico e do profissionalismo democrático A análise parte da concepção de que há uma pluralização das formas identitárias dos grupos profissionais, e que estas identificações resultam da construção negociada entre pares, competidores e público.

Neste sentido, os periódicos dos grupos profissionais e a grande imprensa são instrumentais relevantes para se investigar o processo de negociação em torno da identidade profissional dos juízes. A base de dados é composta da análise de conteúdo de textos sobre juízes, ou escritos por eles, publicados no jornal Folha de S. Paulo, entre 1996 e 2002; da seção de noticiário e dos discursos publicados na Revista de Jurisprudência do Tribunal de Justiça do Estado de São Paulo, entre 1968 e 1997 e dos artigos do jornal Juízes para a Democracia, entre 1992 e 2002. Cada um desses acervos foi classificado em quatro grandes temas, focalizando o ideário profissional, a relação dos juízes com os outros poderes de Estado, a relação interprofissional e intraprofissional e os interesses expressos por eles. O estudo compara estas três bases, para formar um quadro amplo das identificações coletivas dos juízes e desembargadores de São Paulo.

Palavras-chave: magistratura, profissionalismo, ideologias, lutas cognitivas, representações identitárias. 


\section{Ideologies of professionalism under dispute within São Paulo's magistracy}

\section{Maria da Glória Bonelli}

The article compares ideas prevailing at the São Paulo Justice Court with that of the Association of Judges for Democracy and the public image of judges in printed media. It relates the distinct contents of those ideas to theories of civic professionalism and democratic professionalism. The analysis is based on the conception that there is a pluralization of identity forms of professional groups and that those identifications are a result of negotiated construction between peers, competitors, and the public.

Therefore, professional groups' publications and mainstream media are relevant instruments to investigate the process of negotiation about judges' professional identity. The database includes content analysis of the texts about judges or written by them, published on the newspaper Folha de São Paulo from 1996 to 2002; of the news section and speeches published on São Paulo Justice Court's journal Revista de Jurisprudência from 1968 to 1997 and articles on the newspaper Juízes para a Democracia from 1992 to 2002. Each of those collections was classified in four broad themes. focusing on professional ideas, judges' relations to other State powers, the interprofessional and intraprofessional relations and interests expressed by them. The study compares those three bases in order to form a broad picture of São Paulo judges and chief judges' collective identifications.

Key words: Magistracy, Professionalism, Ideologies, Cognitive struggles, Identity representations. 